\title{
Comparison of rapid methods for detection of heat-labile (LT) and heat-stable (ST) enterotoxin in Escherichia coli
}

\author{
EVA CZIROK, G. SEMJÉN*, H. STEINRÜCKT, MARIA HERPAY, HEDDA MILCH, \\ ILDIKO NYOMÁRKAY‡, ZSOFIA STVERTECZKY§ and AGNES SZENESS\|
}

National Institute of Hygiene, "Bela Johan", Gyáli u 2-4, H-1966 Budapest, "University of Veterinary Science, POB H-1400 Budapest, t/nstitut for Infektionskrankheiten i, Kindesalter Berlin-Buch, 0-1115 Berlin-Buch, Germany, $\ddagger$ Public Health Station H-1138 Budapest, §Pest County Public Health Station, H-1032 Budapest and ||Györ-MösonSopron County Public Health Station, H-9024 Györ, Hungary

\begin{abstract}
Summary. Oxoid VET-RPLA, ST-EIA and Pharmacia Phadebact ETEC-LT enterotoxin tests were compared to find a simple but reliable method for detecting enterotoxigenic Escherichia coli (ETEC) in Hungary. In the Oxoid tests, all six reference LT- or ST-producing strains, except one ST-producer, gave positive results. Of 11 reference porcine enterotoxigenic strains, all four LT-producers gave positive reactions for LT but three of 10 ST-producers gave negative reactions for ST. Thirteen of 50 strains from culture collections of $\mathrm{H}$. Steinrück (Germany) were $\mathrm{LT}^{+}$and nine of 33 were $\mathrm{ST}^{+}$. When 31 isolates were tested simultaneously with the Oxoid and the Pharmacia LT tests, 12 strains were $\mathrm{LT}^{+}$by the Oxoid LT test but by the Phadebact LT test only seven of these strains were $\mathrm{LT}^{+}$and, of the remainder, three gave uncertain results and two gave negative results. Of 69 porcine strains, seven were $\mathrm{LT}^{+}$ and three $\mathrm{ST}^{+}$. Of 901 human strains isolated in Hungary, 10 were $\mathrm{LT}^{+}$and one of 24 tested was $\mathrm{ST}^{+}$. In two cases, ETEC strains were isolated from contacts of travellers returning from Mongolia and Bangladesh. Results of comparative studies with reference strains corresponded well to those of the classical toxin detection tests. The Oxoid test was rapid, sensitive, specific and easy to perform and is recommended for use in screening ETEC isolates.
\end{abstract}

\section{Introduction}

Escherichia coli is a common commensal organism in the gut, where most strains are non-pathogenic. However, some can produce diarrhoea by a number of distinct mechanisms. Based on virulence properties, interactions with the intestinal mucosa, clinical symptoms and $\mathrm{O}: \mathrm{H}$ serotypes, diarrhoeagenic $E$. coli strains can be divided into four categories: enterotoxigenic (ETEC), entero-invasive (EIEC), enteropathogenic (EPEC) and enterohaemorrhagic (EHEC). ${ }^{1}$

ETEC are an important cause of diarrhoeal disease in man and animals. ${ }^{2-4}$ In man, ETEC are encountered in tropical areas as endemic pathogens and they are also the agents most frequently responsible for travellers' diarrhoea. Among newborn calves and piglets, scouring elicited by ETEC is also common and causes serious economic losses.

ETEC strains can produce two types of enterotoxins ${ }^{3}$ - LT, a heat-labile enterotoxin ${ }^{5}$ and ST, a heat-stable enterotoxin. ${ }^{6,7}$ Two antigenically different forms of LT - LTI and LTII-are known. ${ }^{8}$ There

Received 13 May 1991 ; revised version accepted 12 Aug. 1991. are also two types of ST - STa is active in a suckling mouse model, ${ }^{9}$ whereas STb causes fluid accumulation in the ligated intestinal loop of pigs but is inactive in the suckling mouse test. ${ }^{10}$ There are two forms of STa-STa1 and STa2. ${ }^{11}$

Several methods have been developed for the detection of enterotoxin: the rabbit ligated-intestinal loop model $; ;^{12,13}$ the rabbit skin test $;{ }^{14}$ the $\mathrm{Y}-1$ adrenal cell assay ${ }^{15}$ and the enzyme-linked immunosorbent assay (ELISA) ${ }^{16}$ However, none of these proved to be suitable for screening for enterotoxigenic $E$. coli strains in routine bacteriological laboratories to determine their incidence.

Recently, ${ }^{17,18}$ some new tests (Oxoid toxin detection kits, Pharmacia Phadebact ETEC-LT test) have become available and offer the possibility of rapid, simple, detection of enterotoxigenic $E$. coli. The Oxoid tests are suitable for the detection of LTI- as well as STa1-and STa2-producing E. coli. ${ }^{11}$

Our aim was to compare the accuracy, sensitivity and specificity of these new tests, and to choose the simplest and most reliable one for screening for enterotoxin producing $E$. coli strains and determining their incidence in Hungary. 


\section{Materials and methods}

\section{Bacterial strains}

A total of 1042 strains was studied. Porcine strains (69) were isolated at a farm where postweaning diarrhoea occurred frequently. The human strains (873) originated from diarrhoeal cases and were isolated during 1981-1983 and in 1990; another 28 strains were isolated by Milch and Gyenes ${ }^{19}$ in 1972. In addition, 11 reference strains and strains from the culture collections of $\mathrm{H}$. Steinrück ( 50 strains) and $\mathrm{G}$. Semjén (11 strains) were used for comparative studies. The latter were tested by Y-1 cell culture, the ligated loop test or the suckling mouse model. All 1042 strains were examined for LT and 80 for ST production by Oxoid tests. Comparative studies of 31 strains were made with the Pharmacia LT and Oxoid LT tests.

\section{Enterotoxin assays}

For detection of LT production, the Oxoid toxin detection kit (VET-RPLA; based on reversed passive latex agglutination) and the Phadebact ETEC-LT test (based on coagglutination) (Pharmacia Fine Chemicals, Uppsala, Sweden) were used according to the instructions of the manufacturers. STa was detected by the Oxoid ST-EIA test based on a competitive enzyme immunoassay. Briefly, for the Oxoid LT test, $E$. coli isolates were inoculated into Mundell's medium-Casein Peptone (Oxoid L42) yeast extract, salt solution (ferric chloride, manganese chloride, magnesium sulphate) - and incubated at $37^{\circ} \mathrm{C}$ for $18 \mathrm{~h}$. Polymyxin B was added to give a concentration of 10000 units $/ \mathrm{ml}$. After further incubation at $37^{\circ} \mathrm{C}$ for $4 \mathrm{~h}$ the culture was centrifuged at $900 \mathrm{~g}$ for $20 \mathrm{~min}$ and the supernate was used as the test sample. For ST detection, strains were inoculated into Casein-Yeast (CA-YE) broth, incubated at $37^{\circ} \mathrm{C}$ for $18 \mathrm{~h}$ and the cultures were centrifuged at $900 \mathrm{~g}$ for $30 \mathrm{~min}$. The supernate was used as the test sample. For the
Phadebact LT test, strains were grown on blood agar and a loopful was suspended in $100 \mu l$ of "extraction solution" for the test sample.

\section{Cell culture assay}

The cytotoxic activity of strains on Vero cells was studied according to the method previously described. ${ }^{20}$

\section{Results}

All the reference LT- and ST-producing strains, except strain P307 which failed to produce ST, were found by the Oxoid tests to produce the expected toxin (table I). Verotoxin-producing E. coli and Shigella dysenteriae serovar 1 strains were found to be enterotoxin-negative. E. coli strains 3 and 4 of serotype $\mathrm{O} 26: \mathrm{H} 11$, reported to be enterotoxigenic, ${ }^{27}$ were found by us to produce verotoxin and they produced neither LT nor ST by the Oxoid tests.

When 11 (Semjén's) porcine enterotoxigenic strains were tested, all four LT-producers gave positive reactions in the Oxoid tests for LT (table II). Of the 10 ST-producing strains (strains whose soft agar culture supernates after heating at $100^{\circ} \mathrm{C}$ for $30 \mathrm{~min}$ caused fluid accumulation in the ligated gut of 5-week-old pigs), seven gave positive results and three gave negative results in the Oxoid ST test. In both tests, no reaction was elicited by the non-enterotoxigenic (P70) strain.

To compare the Oxoid LT (VET-RPLA) and the Pharmacia LT (Phadebact ETEC-LT) tests, 31 isolates were tested simultaneously (table III). By the Oxoid test 12 strains were found to be LT-positive, whereas with the Phadebact test only seven of these strains gave positive results, three gave uncertain results and two were negative. In addition, two Oxoid testnegative strains gave uncertain reactions by the Pharmacia test.

Table I. The results obtained with reference strains with Oxoid toxin detection kits

\begin{tabular}{|c|c|c|c|c|c|}
\hline \multirow{2}{*}{$\begin{array}{c}\text { Strain } \\
\text { designation }\end{array}$} & \multirow{2}{*}{ Reference } & \multirow{2}{*}{$\begin{array}{l}\text { Serogroup } \\
\text { or serotype } \\
\text { of strain }\end{array}$} & \multirow{2}{*}{$\begin{array}{l}\text { Type of toxin } \\
\text { produced }\end{array}$} & \multicolumn{2}{|c|}{ Reaction in the tests } \\
\hline & & & & LT (titre) & ST (OD) \\
\hline PB176 & 21 & E. coli O6:H16 & LT, ST & $+(1: 32)$ & $+(0 \cdot 200)$ \\
\hline P307 & 23,24 & $\mathrm{O} 8: \mathrm{K} 87,88$ & $\mathrm{LT}, \mathrm{ST}^{*}$ & NT & $-(1.083)$ \\
\hline P16 & 22 & $\mathrm{O} 9: \mathrm{K} ?$ & ST & NT & $+(0 \cdot 188)$ \\
\hline H30 & 20 & $\mathrm{O} 26: \mathrm{H} 11$ & VT & $-(<1: 2)$ & $-(1.010)$ \\
\hline H10407 & 25 & O78:H11 & LT, ST & $+(1: 64)$ & $+(0 \cdot 140)$ \\
\hline E57 & 26 & O138:K81 & ST & NT & $+(0 \cdot 163)$ \\
\hline P155 & 24 & O149:K91, 88ac & LT, ST & $+(1: 32)$ & $+(0 \cdot 159)$ \\
\hline $337-85$ & $\mathbf{W}$ & $\mathrm{O} 157: \mathrm{H7}$ & VT & $-(<1: 2)$ & $-(1 \cdot 108)$ \\
\hline 904 & $\mathbf{S}$ & S. dysenteriae 1 & VT & $-(<1: 2)$ & $-(1.084)$ \\
\hline $3+$ & 27 & E. coli $\mathrm{O} 26: \mathrm{H} 11$ & LT & $-(<1: 2)$ & $-(1 \cdot 115)$ \\
\hline $4 \dagger$ & 27 & $\mathrm{O} 26: \mathrm{H} 11$ & $\mathrm{LT}$ & $-(<1: 2)$ & $-(0 \cdot 809)$ \\
\hline
\end{tabular}


Table II. Enterotoxin detection in porcine strains*

\begin{tabular}{|c|c|c|c|c|c|}
\hline \multirow{2}{*}{$\begin{array}{c}\text { Strain } \\
\text { designation }\end{array}$} & \multirow{2}{*}{$\begin{array}{l}\text { Serogroup or } \\
\text { serotype of } \\
\text { strain }\end{array}$} & \multicolumn{2}{|c|}{ Ligated loop test } & \multicolumn{2}{|c|}{ Oxoid test } \\
\hline & & LT & ST & LT & ST \\
\hline SWP99† & $\mathrm{O} 141: \mathrm{K} 85 \mathrm{ab}, 88 \mathrm{ab}$ & + & + & + & + \\
\hline P49† & O138:K81, 88ac & + & + & + & - \\
\hline P9 & Ol49:K91, 88ac & + & + & + & + \\
\hline P30 & $\mathrm{O} 141: \mathrm{K} 88 \mathrm{ac}$ & + & + & + & - \\
\hline P58 & O115:K. & - & + & - & + \\
\hline P783 & O149:K91 & - & + & - & + \\
\hline P862 & O1 $38: K 81$ & - & + & - & + \\
\hline SWP105 & O141:K85 & - & + & - & + \\
\hline SWP3 & $\mathrm{O} 139: \mathrm{K} 82$ & - & + & - & - \\
\hline P70 & O141:K85ab & - & - & - & - \\
\hline P54 & O138:K81 & - & + & - & + \\
\hline
\end{tabular}

+ , toxin formed; - , toxin not formed

* From culture collection of G. Semjén.

+ See ref. 28 for P, and 29,30 for SWP strains.

Thirteen out of 50 German strains (Steinrück collection) were $\mathrm{LT}^{+}$and nine out of 33 were $\mathrm{ST}^{+}$by the Oxoid test (table IV). Eight of these also produced LT and one produced ST only. All but one of the strains found to be $\mathrm{LT}^{+}$when tested in Germany were also positive by the Oxoid test, but seven strains found

Table III. Enterotoxin production by 31 isolates of $E$. coli determined by Oxoid VET-RPLA and Phadebact ETECLT tests

\begin{tabular}{lc}
\hline \multicolumn{1}{c}{ Results } & Number of strains \\
\hline Both tests negative & 17 \\
Both tests positive & 7 \\
Oxoid positive, Phadebact dubious & 3 \\
Oxoid positive, Phadebact negative & 2 \\
Oxoid negative, Phadebact dubious & 2 \\
\hline
\end{tabular}

Table IV. Comparative studies for enterotoxin detection in E. coli strains originating from Germany*

\begin{tabular}{|c|c|c|c|c|}
\hline \multirow{3}{*}{$\begin{array}{l}\text { Oxoid toxin } \\
\text { test result }\end{array}$} & \multicolumn{4}{|c|}{ Number of strains that were } \\
\hline & \multicolumn{2}{|c|}{$\mathrm{LT}+(50)$} & \multicolumn{2}{|c|}{$\mathrm{ST} \dagger(33)$} \\
\hline & $+(14)$ & $-(36)$ & $+(15)$ & $-(18)$ \\
\hline \multicolumn{5}{|l|}{ VET-RPLA (LT) titre } \\
\hline 0 & $1 \ddagger$ & 36 & $\ldots$ & $\ldots$ \\
\hline 4 & 4 & 0 & $\ldots$ & $\ldots$ \\
\hline 8 & 4 & 0 & $\ldots$ & $\ldots$ \\
\hline 16 & 4 & 0 & $\ldots$ & $\ldots$ \\
\hline 64 & 1 & 0 & $\ldots$ & $\ldots$ \\
\hline $4-64(+)$ & 13 & 0 & $\cdots$ & $\cdots$ \\
\hline \multicolumn{5}{|l|}{ ST-EIA (ST) } \\
\hline+ & $\ldots$ & . & 8 & $1 \S$ \\
\hline - & $\ldots$ & $\cdots$ & $7 \S$ & 17 \\
\hline
\end{tabular}

${ }^{*}$ From culture collections of $\mathrm{H}$. Steinrück.

$\dagger$ Tests done in Germany (Y1 and $\mathrm{CHO}$ culture or suckling mouse test).

$\ddagger$ Repeated examination by VET-RPLA gave a negative result (strain probably lost its original toxicity).

$\S$ Repeat tests gave negative results in suckling mouse test (strains probably lost their original toxicity). two years earlier in Germany to be $\mathrm{ST}^{+}$were negative by the Oxoid test. However, it could not be excluded that these strains had lost their original toxicity.

Of the 901 human strains isolated in Hungary from faecal samples or jejunal juice of patients with gastroenteritis, 10 strains, one a strain of Citrobacter freundii, were found to produce LT and none of these produced ST. Six of these were amongst recent (1990) isolates from 300 patients. Of 24 strains tested for ST, one was $\mathrm{ST}^{+}$, but $\mathrm{LT}^{-}$(table V). In two cases, ETEC were isolated from contacts of travellers who had been visiting Bangladesh and Mongolia.

Of the 69 pig strains, seven produced LT only (these were of serogoup 08,0141 and O149) and three produced ST only (these were serogroup 0147 and O157).

\section{Discussion}

Infantile diarrhoea through enterotoxigenic $E$. coli strains is rare in developed countries, but occasional outbreaks have been reported. ${ }^{31}$ Although ETEC strains from widely separated geographic areas belong to a comparatively limited number of serogroups, ${ }^{32}$ the serogroups commonly associated with ETEC (e.g., $\mathrm{O} 6, \mathrm{O} 8, \mathrm{O} 20, \mathrm{O} 25, \mathrm{O} 78$, etc) are also the ones occurring most frequently in the faeces of healthy individuals. ${ }^{33}$ Therefore, serotyping isolates is an unsatisfactory method of detecting ETEC. The only way to detect ETEC is to show LT and/or ST production. Because LT is structurally, antigenically and functionally related to cholera toxin, ${ }^{34}$ detection is based on cholera toxin detection methods. However, these are too complicated and time-consuming for regular use in non-specialist laboratories.

Now rapid and simple tests for enterotoxins based on agglutination are available commercially. ${ }^{35,36}$ Through their use it was shown that ETEC was more commonly associated with diarrhoeal disease in Australia than had been anticipated. ${ }^{37}$ On the other 
Table V. Enterotoxigenic isolates from human cases of enteritis in Hungary

\begin{tabular}{|c|c|c|c|c|c|}
\hline \multirow{2}{*}{$\begin{array}{c}\text { Strain } \\
\text { designation }\end{array}$} & \multirow{2}{*}{ Year of isolation } & \multirow{2}{*}{ Organism, serotype } & \multirow{2}{*}{$\begin{array}{c}\text { Patient } \\
\text { age, source }\end{array}$} & \multicolumn{2}{|c|}{ Oxoid toxin detection tests } \\
\hline & & & & LT (titre) & ST \\
\hline $31 / 5$ & 1979 & C. freundii & $4 \mathrm{~m}$, Faeces & $1: 8$ & - \\
\hline 104918 & 1981 & E. coli $\mathrm{O} 15: \mathrm{H} 25$ & $3 y$, Faeces & $1: 32$ & - \\
\hline 734 & 1983 & $\mathrm{O} 20: \mathrm{H}-$ & $7 y$, jejunal juice & $1: 64$ & - \\
\hline 100007 & 1982 & $\mathrm{O} 20: \mathrm{H}-$ & 5y, Faeces & - & + \\
\hline 95366 & 1982 & $\mathrm{O} 159: \mathrm{H} 4$ & $2 y, \quad$ Faeces & $1: 32$ & - \\
\hline 511 & 1990 & O7:HNT & $60 y$, Faeces & $1: 8$ & - \\
\hline 593 & 1990 & $\mathrm{O} 6: \mathrm{H}-$ & $3 y, \quad$ Faeces & $1: 32$ & _- \\
\hline 635 & 1990 & O7:HNT & 13y, Faeces* & $1: 16$ & _- \\
\hline 636 & 1990 & $\mathrm{O} 6 \mathrm{H} 16$ & $5 y$, Faeces & $1: 8$ & - \\
\hline 637 & 1990 & $\mathrm{O}: \mathrm{H} 16$ & $4 y$, Faeces & $1: 8$ & - \\
\hline 668 & 1990 & $\mathrm{O} 6: \mathrm{H} 16$ & $27 \mathrm{y}$, Faeces $\dagger$ & $1: 4$ & - \\
\hline
\end{tabular}

+ , Toxin detected; - , no toxin detected; NT, not typable.

* Patient's father recently returned from Bangladesh.

$\dagger$ Patient's husband returned from Mongolia where he had enteritis.

hand, Scotland et al. ${ }^{38}$ recommended the Oxoid LT test for detecting the presence of $\mathrm{LT}^{+}$strains because of its high specificity, ease of performance and speed. Almeida et al.$^{18}$ examined $V$. cholerae enterotoxigenic strains by this test and supported this view.

When the Oxoid LT test and the Phadebact LT test were compared, the former proved to be more sensitive. In some cases, in addition to falsely negative results, the Phadebact test gave unclear results. However, the results of the Oxoid test on the reference enterotoxigenic strains agreed with those determined by other assays. On the basis of our findings, we recommend use of Oxoid tests, because they are rapid, sensitive, specific and easy to perform.

The Oxoid test was less useful in detecting STproducing $E$. coli among porcine isolates. ${ }^{39}$ Moreover, as this test uses plates with precoated wells, it is not an efficient method for testing small numbers of isolates from sporadic cases.

Our results also show that the Oxoid LT and ST tests can differentiate LT and ST production from production of other cytotoxins. As expected, strain

\section{References}

1. Levine MM. Escherichia coli that cause diarrhea: enterotoxigenic, enteropathogenic, enteroinvasive, enterohemorrhagic and enteroadherent. $J$ Infect Dis 1987; 155: $377-$ 389.

2. Gorbach SL, Banwell JG, Chatterjee BD, Jacobs B, Sack RB. Acute undifferentiated human diarrhea in the tropics. $J$ Clin Invest $1971 ;$ 50: $881-889$.

3. Smith HW, Gyles CL. The relationship between two apparently different enterotoxins produced by enteropathogenic strains of Escherichia coli of porcine origin. J Med Microbiol $1970 ; 3: 387-401$

4. Sack DA, Kaminsky DC, Sack RB et al. Prophylactic doxycycline for travellers' diarrhea. Results of a prospective double-blind study of peace corps volunteers in Kenya. $N$ Engl J Med 1978; 298: 758-763.

5. Evans DJ, Chen LC, Curlin GT, Evans DG. Stimulation of adenyl cyclase by Escherichia coli enterotoxin. Nature New Biol 1972; 236 : 137-138.

6. Aldrete JF, Robertson DC. Purification and chemical charac-
$\mathrm{H} 30$ of serotype $\mathrm{O} 26: \mathrm{H} 11$ and a VT-producer ${ }^{20}$ gave negative results in tests for ST and LT. Previous tests, ${ }^{13,27,40}$ in which VT-producers were tested in animal models, gave inconsistent results although it has been shown that purified VT is active in the rabbit ileal loop model. In this study we found that strains 3 and 4, also of serotype $\mathrm{O} 26: \mathrm{H} 11$ and previously considered to produce an altered $\mathrm{LT}^{27,41}$ gave negative results for LT and ST by the Oxoid tests but positive results in a test for VT. Thus, the specificity of Oxoid LT and ST tests can preclude such confusions in classification of ST, LT or VT.

This work has revealed that LT-producing strains are also involved in human diarrhoeal disease in Hungary. The detection of an LT-producing $C$. freundii strain is interesting, particularly because our recent examinations of an outbreak of diarrhoea showed $\mathrm{ST}^{+}$ strains of $C$. freundii to be the aetiological agent. Our public health laboratories have started to search for toxigenic isolates in diarrhoeal epidemics of unknown origin by the rapid, simple Oxoid tests.

terization of Escherichia coli heat-stable enterotoxin. Annual Meeting of the American Society for Microbiology. 1977: 33, Abstract no. B105.

7. Pesti L, Semjén G. Escherichia coli vaccine for prevention of neonatal enteric colibacillosis in pigs. Acta Vet Acad Sci Hung 1980; 28 : 1-11

8. Holmes RK, Twiddy EM, Pickett CL. Purification and characterization of type II heat-labile enterotoxin of Escherichia coli. Infect Immun 1986; 53: 464-473.

9. Burgess MN, Bywater RJ, Cowley CM, Mullan NA, Newsome PM. Biological evaluation of a methanol-soluble, heatstable Escherichia coli enterotoxin in infant mice, pigs, rabbits and calves. Infect Immun 1978; 21 : 526-531.

10. Greenberg RN, Guerrant RL. Escherichia coli heat-stable enterotoxin. Pharmacol Ther 1981; 13: 507-531.

11. Scotland SM, Willshaw GA, Said B, Smith HR, Rowe B. Identification of Escherichia coli that produces heat-stable enterotoxin $\mathbf{S T}_{\mathrm{A}}$ by a commercially available enzymelinked immunoassay and comparison of the assay with infant mouse and DNA probe tests. J Clin Microbiol 1989; 27: 1697-1699. 
12. De SN, Bhattacharya K, Sarkar JK. A study of the pathogenicity of strains of Bacterium coli from acute and chronic enteritis. J Pathol Bacteriol 1956; 71 : 201-209.

13. Taylor J, Bettelheim KA. The action of chloroform-killed suspensions of enteropathogenic Escherichia coli on ligated rabbit-gut segments. J Gen Microbiol 1966; 42: 309-313.

14. Craig JP. A permeability factor (toxin) found in cholera stools and culture filtrates and its neutralization by convalescent cholera sera. Nature $1965 ; 207$; 614-616.

15. Sack DA, Sack RB. Test for enterotoxigenic Escherichia coli using Y1 adrenal cells in miniculture. Infect Immun 1975; 11 : $334-336$

16. Yolken RH, Greenberg HB, Merson MH, Sack RB, Kapikian AZ. Enzyme-linked immunosorbent assay for detection of Escherichia coli heat-labile enterotoxin. J Clin Microbiol $1977 ; 6: 439-444$.

17. Bettelheim KA, Gracey $M$, Wadström $T$. The use of coagglutination test to determine whether Australian and New Zealand isolates of Escherichia coli produce the heat-labile enterotoxin. Zentralbl Bakteriol Hyg A 1985; 260: 293-299.

18. Almeida RJ, Hickman-Brenner FW, Sowers EG, Puhr ND Farmer JJ, Wachsmuth IK. Comparison of a latex agglutination assay and an enzyme-linked immunosorbent assay for detecting cholera toxin. $J$ Clin Microbiol 1990 28: $128-130$

19. Milch H, Gyenes $\mathbf{M}$. Subdivision and correlation studies of serologically grouped Escherichia coli strains by phage typing, colicinogency, lysogeny and biochemical test. Acta Microbiol Acad Sci Hung 1972; 19: 213-244.

20. Konowalchuk J, Speirs JI, Stavric S. Vero response to a cytotoxin of Escherichia coli. Infect Immun 1977; 18: 775779.

21. Evans DG, Evans DJ. New surface-associated heat-labile colonization factor antigen (CFA/II) produced by enterotoxigenic Escherichia coli of serogroups $\mathrm{O6}$ and 08 . Infect Immun 1978; 21 : 638-647.

22. Gyles CL. Heat-labile and heat-stable forms of the enterotoxin from $E$. coli strains enteropathogenic for pigs. Ann $N Y$ Acad Sci 1971; 176: 314-322.

23. Lee CH, Moseley SL, Moon HW, Whipps SC, Gyles CL, So M. Characterization of the gene encoding heat-stable toxin II and preliminary molecular epidemiological studies of enterotoxigenic Escherichia coli heat-stable toxin II producers. Infect Immun 1983; 42: 264-268.

24. Gyles CL. Immunological study of heat-labile enterotoxins of Escherichia coli and Vibrio cholerae. Infect Immun 1974; 9 : 564-570.

25. Evans DJ, Evans DG. Three characteristics associated with enterotoxigenic Escherichia coli isolated from man. Infect Immun 1973; 8: 322-328

26. Sojka WJ. Enteropathogenic Escherichia coli in man and farm animals. Symposium on microbial food-borne infections and intoxications, Ottawa. 1972:5-17.
27. Kétyi I, Czirók E, Vertényi A, Málovics I, Pácsa S. Comparison of Escherichia coli enterotoxin tests. Acta Microbiol Acad Sci Hung 1978; 25 : 23-36.

28. Pesti L, Semjén G. Studies on enteropathogenicity, loop dilating effect and enterotoxin producing capacity of Escherichia coli strains isolated from enteric diseases of swine. Acta Vet Acad Sci Hung 1973; 23: 227-236.

29. Smith HW, Halls S. Observations by the ligated intestinal segment and oral inoculation methods on Escherichia coli infections in pigs, calves, lambs and rabbits. $J$ Pathol Bacteriol 1967; 93: 499-529.

30. Smith HW, Gyles CL. The effect of cell-free fluids prepared from cultures of human and animal enteropathogenic strains of Escherichia coli on ligated intestinal segments of rabbits and pigs. J Med Microbiol 1970; 3: 403-409.

31. Ryder RW, Wachsmuth IK, Buxton AE et al. Infantile diarrhea produced by heat-stable enterotoxigenic Escherichia coli. $N$ Engl J Med 1976; 295: 849-853.

32. Ørskov F, Ørskov I, Evans DJ, Sack RB, Sack DA, Wadström T. Special Escherichia coli serotypes among enterotoxigenic strains from diarrhoea in adults and children. Med Microbiol Immunol (Berlin) 1976; 162: 73-80.

33. Czirók É, Martön A, Csik M, Solt M. Virulence factors of Escherichia coli I. Mannose resistant haemagglutinating capacity is associated with serogroup but not with site of infection. Acta Microbiol Hung 1984; 31 : 187-195.

34. Field M. Modes of action of enterotoxins from Vibrio cholerae and Escherichia coli. Rev Infect Dis 1979; 1: 918-925.

35. Rönnberg B, Wadström $T$. Rapid detection by a coagglutination test of heat-labile enterotoxin in cell lysates from blood agar-grown Escherichia coli. J Clin Microbiol 1983; 17: 1021-1025.

36. Finkelstein RA, Yang Z. Rapid test for identification of heatlabile enterotoxin-producing Escherichia coli colonies. $J$ Clin Microbiol 1983; 18: 23-28.

37. Bettelheim KA, Hanna N, Smith DL, Dwyer BW. Evaluation of the Phadebact ETEC-LT test for heat-labile enterotoxin of Escherichia coli. Zentral Bakteriol 1989; 271 : 70-76.

38. Scotland SM, Flomen RH, Rowe B. Evaluation of a reversed passive latex agglutination test for the detection of Escherichia coli heat-labile toxin in culture supernatants. $J$ Clin Microbiol 1989; 27 : 339-340.

39. Whipp SC. Protease degradation of Escherichia coli heat-stable, mouse-negative, pig-positive enterotoxin. Infect Immun 1987; 55: $2057-2060$.

40. Evans DG, Evans DJ, Gorbach SL. Identification of enterotoxigenic Escherichia coli and serum antitoxin activity by the vascular permeability factor assay. Infect Immun 1973; 8: 731-735.

41. Kétyi I, Emödy L, Pácsa S, Vertényi A, Kontrohr T. An altered heat-labile enterotoxin (LT') produced by Escherichia coli serogroup O55 strain. Acta Microbiol Acad Sci Hung 1979; 26: $255-262$. 